Meta

Journal des traducteurs

Translators' Journal

\title{
Translating Arabic Into English: Basic Considerations in Word Order
}

\section{Menacere}

Volume 40, numéro 4, décembre 1995

URI : https://id.erudit.org/iderudit/003628ar

DOI : https://doi.org/10.7202/003628ar

Aller au sommaire du numéro

Éditeur(s)

Les Presses de l'Université de Montréal

ISSN

0026-0452 (imprimé)

1492-1421 (numérique)

Découvrir la revue

Citer cet article

Menacere, M. (1995). Translating Arabic Into English: Basic Considerations in Word Order. Meta, 40(4), 606-613. https://doi.org/10.7202/003628ar
Résumé de l'article

On discute des difficultés relatives à l'ordre des mots lors de la traduction de l'arabe vers l'anglais. L'auteur démontre que la richesse de la morphologie de l'arabe donne une plus grande flexibilité dans l'ordre des mots que ne le permet l'anglais et se demande dans quelle mesure cela peut engendrer des problèmes de traduction. 


\title{
TRANSLATING ARABIC INTO ENGLISH: BASIC CONSIDERATIONS IN WORD ORDER
}

M. Menachere

Liverpool. United Kingdom

\begin{abstract}
Résumé
On discute des difficultés relative's à l'ordre des mots lors de la traduction de larabe vers l'anglais. L'auteur démomere que la richesse de la morphologie de larabe donne une plus grande flevihilité dans l'ardre de's mots que ne le permet lamplasis at se demande dans quelle mesure cela peat engendrer de's problemess de traduction.
\end{abstract}

\begin{abstract}
This paper attempts to discuss the potential difficulties in ranslating Arabic into English nith regard to word order. Arabic has a richer morphology than English and this enables morphological discrimination of surface grammatical relations in a way that is usually impossihle in English. As a result. Arabic word order is freer than English with Arabic in general allowing any permusation of the major constime'ns without loss of grammasicality or change in the basic cognitive meaning of the sentence This paper looks at whether this flexibility in Arabic word order constitute's a ranslating problem.
\end{abstract}

\section{INTRODUCTION}

The basic assumption of contrastive analysis is that while languages such as Arabic and English are different, there is always a similarity between them. This is supported by the fact that most of what is written or said in one language can be translated into another. Thus, no matter how great the difference in isolated linguistic features between the languages, it is possible to render the message from one discourse into another. Since we communicate in discourse, we cannot translate isolated items or sentences meaningfully unless they are embedded in a particular context of situation.

Arguably, the closer the culture and civilization of the users of various languages, the greater the resemblance there will be between the communicative purposes covered by their languages. In the case of Arabic / English, one is not only talking of two different linguistic systems but also of a clash between two different cultural worlds. Consequently, in terms of translation, one expects possible complications and incompatibilities. Even where there is formal correspondance i.e. a straightforward transfer or full compatibility between the two languages, there are still areas in one language which have no counterpart in the other or where some features or sentence patterns present in the structure of English are represented by different means in Arabic. In other words, features and grammatical components are distributed differently in the two languages. In what follows, the way Arabic distributes its grammatical components in a sentence, will be illustrated.

While English can be said to have a pragmatically controlled word order. Arabic displays more flexibility in the distribution and movement of its components. Although Arabic tolerates variations in word order. it can be argued that, in general, the underlying order of the common surface elements is VSO as, for example, in: 


$\begin{array}{ccc}\text { akala } & \text { al-waladu } & \text { tufahatan } \\ V & S & O \\ \text { ate } & \text { the boy } & \text { an apple }\end{array}$

with the verb characteristically and predominantly in front and subject to inflection for number, gender and person e.g.

$\begin{array}{ccc}\text { akalat } & \text { al-bintu } & \text { tufahatan } \\ V & S & O \\ \text { ate she } & \text { the girl } & \text { an apple }\end{array}$

But when the language user intervenes and disrupts this order, for instance when a noun phrase is fronted i.e. the subject precedes its verb, it yields an SVO order e.g.

$$
\begin{array}{ccc}
\text { al-waladu } & \text { akala } & \text { tufahatan } \\
\mathrm{S} & \mathrm{V} & \mathrm{O}
\end{array}
$$

meaning the sentence begins with a noun. This is called a nominal sentence as opposed to the verb in its 'normal' position i.e. at the beginning which is known as a verbal sentence. Although the basic order is VSO, Arabic is more tolerant of variations in word order (as will be illustrated). By basic it is meant unmarked i.e. not restricted to a specific context or stage of communication. When a word order is said to have a basic order, such a notion of basicness is established on the basis of frequency, neutrality and unrestricted occurrence. It can be said then, that the criteria used to determine basicness of one word order. out of a number of orders that a given language may allow, are thus pragmatic in nature.

The other variations of word order which are permissible in Arabic can be derived from the basic order VSO by shifting the subject or object to a position of emphasis.

\begin{tabular}{|c|c|c|c|c|}
\hline I. & $\begin{array}{l}\text { akala } \\
V \text { ate }\end{array}$ & $\begin{array}{l}\text { al-waladu } \\
S \text { the boy }\end{array}$ & $\begin{array}{l}\text { tufahatan } \\
O \text { an apple }\end{array}$ & (VSO) \\
\hline 2. & $\begin{array}{l}\text { al-waladu } \\
S \text { the boy }\end{array}$ & $\begin{array}{l}\text { akala } \\
V \text { ate }\end{array}$ & $\begin{array}{l}\text { tufahatan } \\
O \text { an apple }\end{array}$ & (SVO) \\
\hline 3. & $\begin{array}{l}\text { al-waladu } \\
S \text { the boy }\end{array}$ & $\begin{array}{l}\text { tufahatan } \\
\text { O an apple }\end{array}$ & $\begin{array}{l}\text { akala } \\
V \text { ate }\end{array}$ & (SOV) \\
\hline 4. & $\begin{array}{l}\text { akala } \\
V \text { ate }\end{array}$ & $\begin{array}{l}\text { tufahatan } \\
\mathrm{O} \text { an apple }\end{array}$ & $\begin{array}{l}\text { alwaladu } \\
S \text { the boy }\end{array}$ & (VOS) \\
\hline 5 . & $\begin{array}{l}\text { al-tufahata } \\
\mathrm{O} \text { an apple }\end{array}$ & $\begin{array}{l}\text { akala(ha) } \\
\text { V ate (it) }\end{array}$ & $\begin{array}{l}\text { alwaladu } \\
S \text { the boy }\end{array}$ & (OVS) \\
\hline 6. & $\begin{array}{l}\text { al-tufahata } \\
\mathrm{O} \text { an apple }\end{array}$ & $\begin{array}{l}\text { al-waladu } \\
S \text { the boy }\end{array}$ & $\begin{array}{l}\text { akala(ha) } \\
\text { V ate (it) }\end{array}$ & (OSV) \\
\hline
\end{tabular}
Consider, for instance, the following examples:

Except for sentence 1 (VSO) which is unmarked, the rest of the orders are said to be marked. Markedness means that the orders are less frequent and that they are restricted in their context of use. In addition, the above orders (VSO excluded) are marked semantically and formally: semantically, either the subject or object NP is made prominent by being shifted to the initial position; and formally, orders whose object NP precedes the verb have the characteristic of hearing a compulsory clitic pronoun suffixed to the verb as in examples 5 and 6. Finally, because Arabic generally marks the subject and object of a 
sentence with case endings (dama and fat-ha diacritics respectively), it is possible to shift the word order without changing the grammatical relationships between the words $e . g$.

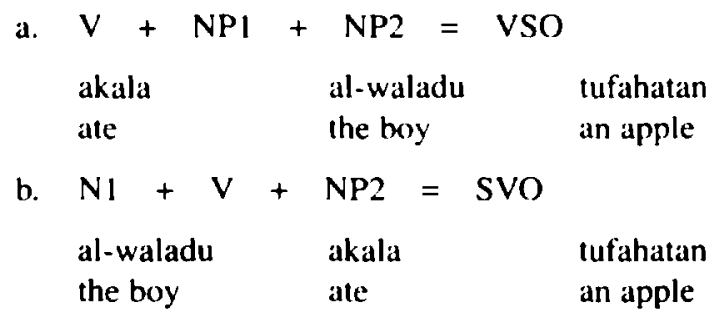

As can be noticed, the two examples above contain the same information and the same components. The order of these components, however. is not the same in the two constructions. In both examples tufahatan (object) is final, but notice that the subject alwaladu in (b) precedes the verb whereas it follows the verb in (a). The subject movement can be said to be shifting. the focus in (b) is on the actor (doer) whereas in (a) it is the act that is focussed upon. The order VOS as in:
akala
tufahatan
al-waladu
$\mathrm{V}$ ate
$O$ an apple
$\mathrm{S}$ the boy

can be accounted for by deriving it transformationally from the underlying VSO order through a movement process by which components of various syntactic categories move to a position immediately to the right of the verb. As for OVS order as in:
al-tufahata
akalaha
al-waladu
$O$ an apple
$V$ ate (it)
S the boy

which is another possible variation, it involves the shifting of focussed components to the left of the verb. The NP is fronted to signal emphasis. The result, however, can only be a derivation unless a morphological marker (clitic pronoun) is inserted to occupy the position vacated by the NP object.

Arabic word order can thus move any constituents, whether NP, adverbial or PP to either the left or the right of the verb. This flexibility, some contend, make the sentence structure ambiguous and the components not easy to isolate. It can be argued, however, that if word order i.e. order in which language components are organized, can be regarded as a manifestation of the language user's intention in discourse, then the function of the different word order variations serves a communicative purpose. Whereas in English. grammatical components are for the most part determined positionally and constraints are imposed on manipulating the word order. Arabic is more tolerant in the movement of its components. As Bakir (1980; 33) points out: "practically, the constituents to the right of the verb can be placed in any order and the resulting sentences will still be acceptable, though to varying degrees." The occurrence of components of different syntactic categories before the verb is what Bakir (1980) calls "pre-verbal displacement," i.c. the placing of components to the left of the verb instead of to the right of the verb. Consider the following examples:
1. akala
V ate
al-waladu
tufahatan $S$ the boy
$O$ an apple
al-tufahata
O an apple
akalaha
al-waladu
$O$ an apple $\quad V$ ate it
$S$ the boy 
3.

4.

5.

6.

7.

8. safara $\checkmark$ travelled

al-barihata Adv yesterday

dhahaba $V$ went

ila al-madrasati PP to the school

shahad

$\checkmark$ saw

dahikan

Adv laughing al-waladu

$S$ the boy

safara

$V$ travelled

al-waladu

$S$ the boy

dhahaba

$V$ went

aal-waladu

$S$ the boy

shahada

V saw al-barihata

Adv yesterday

al-waladu

$S$ the boy

ila al-madrasati

PP to the school

a)-waladu

$S$ the boy

$\begin{array}{ll}\text { 3liyan } & \text { dahikan } \\ \text { O Ali } & \text { Adv laughing } \\ \text { al-waladu } & \text { 3liyan } \\ \text { S the boy } & \text { O Ali }\end{array}$

Components in sentences $2,4,6$ and 8 assumed position to the left of the verb i.e. preverbal, while in sentences $1,3,5$ and 7 these components occured to the right of the verb i.e. post-verbal. The relationship between the first and the second set is not the same. Sentence 2 starts with NP object, sentence 4 starts with an NP component in the form of an adverb of time, sentence 6 starts with a prepositional phrase which is also a component of an NP while sentence 8 starts with a noun as a masdar + an (morpheme) functioning as an adverb of manner.

Thus the sentences of the first set can be said to be all NP components. The purpose of NP components fronting in Arabic discourse follows a pragmatic function that NP's convey a particular communicative function, i.e. of description. NP's are marked for case and in any movement of NP to the left of the verbs must include its case marking.

So far, we have dealt with word order which involved NP components in pre-verbal positions $i$.e. to the left of the verb, such as object, adverbial, prepositional phrases and adverbs of manner in the form of masdar. Let us now consider word order with subject NP fronting e.g.

$$
\begin{gathered}
\text { al-waladu } \\
\text { S }
\end{gathered}
$$

tufahatan

O

instead of the basic VSO. As illustrated, Arabic word order seems to exhibit a relative freedom in moving any constituents whether NP, adverbial or PP to either the left or the right of the verb. This flexibility is, however, controversial. The issue that is much in dispute here is whether or not subjects can precede verbs. Wright (1955: 251) points out:

the difference between verbal and nominal sentences, to which the native grammarians attach no small importance, is properly this, that the former relates an act or event, the latter gives a description of a person, or thing either absolutely or in the form of a clause descriptive of a state. This is the constant rule in good old Arabic, unless the desire to emphasize a part of the sentence be the cause of change in its position.

Advocates of the grammar school Al-Basrah, refuted the idea that a subject can precede its verb. claiming that the order of the subject is a strict one and they demonstrated this view in detail. It would be beyond the scope of this paper to elaborate on their arguments here, but it is pertinent to note that their main objection against subject NP being put to the left of the verb lies in the fact that: 

al-waladu
akala
tufahatan
$S$ the boy
$\mathrm{V}$ ate
$O$ an apple

is derived from the order:
akala
al-waladu
Iufahatan
$\mathrm{V}$ ate
$\mathrm{S}$ the boy
O an apple

and that the shifting of subject to the left of the verb creates ambiguity on the grounds that when the subject is to the right, the verb agreement differs from that when the subject is to the left of the verb. In verb initial sentences, the verb agrees with its subject in person and gender particularly in third person subject. However, if the subject is moved to the left of the verb, the verb has to agree with it not only in person and gender but in number as well. Agreement in number when the subject is to the right of the verb is not permitted. e.g.

\begin{tabular}{|c|c|c|}
\hline la. & $\begin{array}{l}\text { jaa } \\
\text { V came }\end{array}$ & $\begin{array}{l}\text { al-a3ibuna (verb singular }- \text { subject plural) } \\
S \text { players }\end{array}$ \\
\hline b. & $\begin{array}{l}\text { al-la.3ibuna } \\
\mathrm{S}\end{array}$ & $\begin{array}{l}\text { jau: (subject plural — verb plural) } \\
V\end{array}$ \\
\hline 2a. & $\begin{array}{l}\text { shahada } \\
V \text { watched }\end{array}$ & $\begin{array}{l}\text { abi wa umi al-muqabala (v.sing. - s.dual) } \\
S \text { father + mother O the match }\end{array}$ \\
\hline b. & $\begin{array}{l}\text { abi wa umi } \\
\text { S }\end{array}$ & $\begin{array}{l}\text { al-muquabala (s. dual - v.dual) } \\
\mathrm{O}\end{array}$ \\
\hline $3 a$. & $\begin{array}{l}\text { tatbikhu } \\
\text { V cook }\end{array}$ & $\begin{array}{l}\text { al-akla (v.sing - s.plural) } \\
\text { O the meals }\end{array}$ \\
\hline & $\begin{array}{l}\text { al-umahat } \\
\mathrm{S}\end{array}$ & $\begin{array}{l}\text { al-akla (s.plural - v.plural) } \\
\text { O }\end{array}$ \\
\hline
\end{tabular}

The number agreement markers on the verbs in sentences $1 \mathrm{~b}, 2 \mathrm{~b}$ and $3 \mathrm{~b}$ are taken by some Arab grammarians to be the subject $i . e$. verb endings such as $u: a$ and $n a$ constitute the subjects of their respective sentences, whereas initial NP's such as:

al-lasibuna, ahi na umi and al-umahat

are considered as a 'mubtada' (subject-theme) which is followed by a verb suffixed with a subject pronoun in the form of a morpheme and the verbal clause is said to be 'khabar' (complement-rheme) to the subject 'mubtada'. Their argument is that the first NP is not a subject $i . c$ '. 'fa3il' (doer), but a 'mubtada' (subject-theme) because subjects do not precede their verbs and hecause the verb already has a subject i.e. in the form of a suffixed pronoun to its verb, and since there is only one subject to a verb, the NP left of the verb cannot be considered subject. The confusion that may arise is partly in the terminology itself. As seen above. Arahic terms the subject of a verbal sentence "fa 3 il' (doer) and the subject of a nominal sentence, which is one where the noun fronts, 'mubtada' (frontal noun). It can be argued however, that there is no evidence of either morphological or structural nature which could prevent the occurrence of SVO in a sentence. It is perhaps for stylistic reasons that the traditional order of VSO is often favoured by communicators.

Nevertheless. the Basrah School of Grammarians maintained their argument that initial NP elements as in sentences $I h, 2 \mathrm{~b}$ and $3 \mathrm{~b}$ are not overt subjects and supported this 
view by supplying examples of instances where an overt subject is missing, e.g. in questions and answers such as:

\begin{tabular}{|c|c|c|c|}
\hline Q.: & $\begin{array}{c}\text { madha } \\
\text { what }\end{array}$ & $\begin{array}{c}\text { talaba } \\
\text { demanded }\end{array}$ & $\begin{array}{l}\text { al-3umalu? } \\
\text { the workers }\end{array}$ \\
\hline A.: & talabu & raf3a & al-ujur \\
\hline & $\frac{V}{\text { demanded }}$ & $\underset{\text { rise }}{S}$ & $\begin{array}{c}\mathrm{O} \\
\text { the salaries }\end{array}$ \\
\hline
\end{tabular}

There is no overt subject in the answer. This, say the grammarians, confirms that number markers suffixed to the verbs are themselves subjects, otherwise sentences of this type would he subjectless.

It can be argued however, that the views put forward by the Basrah School of Grammar rejecting the NP initial in subject position to the left of the verb, appear to overlook the communicative intention of the language user and that the pragmatic purposes such as 'focus' can involve more or less any linguistic element which the language user deems necessary to communicate his wishes. Bakir (1980: 129) confirms this view: "When the most salient element in the sentence is moved to a pre-verbal position, there is no reason that a 'focused' subject should be blocked from undergoing such a process."

It seems reasonable to suggest, that the shifting movement of the subject must therefore be examined in a discourse framework. If the communicator wishes to emphasize an item in discourse, he should place it where attention is at its highest i.e. at the beginning. It can thus be argued, that NP initial position implies a position of communicative prominence. If it is accepted that word order reflects the natural pattem of a speech community, VSO and SVO orders may be looked upon as a means which reproduces the order of ideas and thoughts of the speaker to communicate his intentions. Word order may then be regarded as a manifestation of the language user's intention in discourse, and the function of the different word order variations serves particular communicative purposes.

In so far as languages differ in the way they mark a communicative purpose, language users, therefore, tend to express their intentions and experiences differently according to the linguistic categories provided by their respective languages. These cognitions tend to have certain effects on word order, for instance, Arabic speakers often tend to convey language purposes starting with a verb. However, since the main concern is the production of a communicative and effective translation, it is sufficient to remember that when considering Arabic discourse for translation into English, some instances will usually be found in which the codification of a given range of experience or communicative purpose differs between the two languages. Although Arabic has basically an unmarked VSO order, while English has an unmarked SVO order, other variations in word order in both languages do exist and the translator should be aware of the occurrence of these variations in discourse.

Up till now, it has been assumed that the Arabic speaker is free to shift any language components to the left or right of the verb as he pleases. But as will be illustrated in the following examples the movement of certain components is restricted by structural constraints of different kinds. For instance NP's that are object masdar + an or PP's or adverbs that are related to these object masadir, cannot move to the right of the verb as constructions of this type are considered ungrammatical e.g.:
* jaa
siyaratan
al-waladu
rakiban
$\checkmark$ came
Ocar
S the boy
Adv riding 


$\begin{array}{lllll}\text { * qala } & \text { amamahu } & \text { al-waladu } & \text { 3umaran } & \text { dahikan } \\ V \text { said } & \text { Adv before } & S \text { the boy } & \text { OOmar } & \text { Adv laughing }\end{array}$

whereas sentences with NP's, PP's and adverbs to the left of the verb are permissible $e . g$.:

$\begin{array}{llll}\text { siyaratan jaa } & \text { al-waladu } & \text { rakiban } & \\ \text { Ocar } & V \text { came } & S \text { the boy } & \text { Adv riding } \\ \text { amama } & \text { al-beiti } & \text { wayafa } & \text { al-waladu } \\ \text { Adv in front of } & \text { the house } & V \text { stood } & S \text { the boy }\end{array}$

\section{CONCLIUSION}

As can be observed. Arabic and English tend to emphasize different aspects of logic in their written and spoken discourse. The richer morphology of Arabic often permits retrieval of the surface grammatical relations directly from the morphological inflections, whereas English relies heavily on word order for encoding of surface grammatical relations. Translation problems related to differences between Arabic and English sentence patterns may be said to stem from the fact that the two languages differ according to which information must be essentially encoded in discourse. The flexibility of Arabic word order requires from the translator a careful reformulation and restructuring to achieve the communicative purpose in English. The important point is that the translator is not concerned with explaining how equivalence is established between Arabic and English sentence patterns, but rather how communication takes place in the most effective way between the transmitter of the Arabic discourse and the ultimate receptor of the translated text in English, via the translator who is both the receptor and transmitter of the translated discourse.

RFFERENCES

BAKIR, M. J. (1980): Aspects of Clause Siructure: A Study of Word Order Variation in Liferary Arabis, Indiana. Indiana (Iniversity Linguistic Club.

WRIGHT, W. (1955): A Grammar of the Arabic Language Vol 2, Cambridge. Cambridge University Press. 
TRANSLATING ARABIC INTO ENGLISH

APPENDIX 1 : FULL. TRANSLITERATION TABLE.

\begin{tabular}{|c|c|c|c|}
\hline $\mathbf{a}$ & i & $\mathrm{DH}$ & ip \\
\hline b & بـ & $\mathrm{T}$ & $b$ \\
\hline$t$ & $\ddot{\sim}$ & $\mathrm{Dh}$ & $\dot{b}$ \\
\hline th & $\ddot{~}$ & 3 & $\varepsilon$ \\
\hline $\mathrm{j}$ & 乙 & gh & $\dot{\varepsilon}$ \\
\hline h & $\tau$ & f & ف \\
\hline kh & $\dot{\tau}$ & $q$ & ن் \\
\hline d & 3 & $k$ & (3) \\
\hline $\mathrm{dh}$ & $j$ & 1 & $J$ \\
\hline $\mathbf{r}$ & 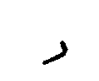 & $\mathrm{m}$ & r \\
\hline$x$ & j & $\mathbf{n}$ & $\dot{ن}$ \\
\hline$s$ & ه & $\mathbf{H}$ & $b$ \\
\hline sh & نن & $w$ & 9 \\
\hline S & $\varphi$ & $y$ & 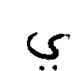 \\
\hline
\end{tabular}

